\title{
A közszolgáltatás-szervezés a levéltári igazgatás területén
}

\section{HORVÁTH ISTVÁN ${ }^{1}$}

Tanulmányomban azt vizsgálom, hogy szervezetelméleti szempontból milyen döntéseket kell meghozni az állami vagy önkormányzati igazgatás területén (esetleg a magánszféra bevonása útján) a kulturális ágazat sajátos jellemzöjü szegmensét képezö, a levéltári igazgatásban történő közszolgáltatás-szervezés hatékonyságának növelése érdekében. Arra a megállapitásra jutottam, hogy e közszolgáltatások megszervezése során eredményesebb megoldást jelent egy hierarchikus rendszerben müködö, területi szervezeti gyakorlat, mint egy decentralizált szervezési elveken nyugvó önkormányzati fenntartásban lévő intézményi struktúra. Álláspontom szerint ez a szabályozás optimálisabb helyzetet teremt a szakterületen: egyrészt a központi irányítás nagyobb mértékben képes azonos feltételeket teremteni, illetve egységes irányt mutatni a funkcionális (pénzügyek, üzemeltetés, koordináció), illetve a szakmai munkának; másrészt e levéltári szervezet sem zárja ki a helyi sajátosságok érvényesülését.

Kulcsszavak: közszolgáltatás-szervezés, levéltári igazgatás területe, hierarchikus, decentralizált

\section{Public Service Management within the Specific Field of Archives}

This paper analyses the potential decisions to be made in order to improve the efficiency of archives management (either state or local government based versions). The conclusion of the paper is that a central, hierarchical management system with territorial units is a better option than a decentralised institutional solution, since the central management could provide the same conditions and unified directions to the professional and functional (budgetary, maintenance and coordination work) staff. However, with the territorial units, the organisations of the archives could even support the local particularities to be achieved.

Keywords: public service management, specific field of archives, hierarchical management, decentralised institutional solution

1 Osztályvezető, Győr-Moson-Sopron Megyei Kormányhivatal, e-mail: horvathistvan8173@ gmail.com 


\section{Közszolgáltatások szervezése a kulturális szektorban}

Kutatásom során elemeztem az államnak a közszolgáltatás-szervezési tevékenysége során tanúsított szerepvállalása mértékét, amelynek a közigazgatás-tudományban megjelent tanulmányokban megfogalmazott jellemzései alapján a „szélső értékeket” tekintve egy, csak a legszükségesebb mértékben eljáró apparátus, valamint egy intervencionista kormányzat képe körvonalazódott ki. Vajon a levéltári igazgatás területén milyen attitűd szükséges a kormányzatok részéről? Elegendő, ha a kormányzat megteremti a vonatkozó jogszabályi környezetet, intézményi hátteret, illetve a közszolgáltatás-szervezés esetleg piaci alapon is megoldható? Milyen eszközökkel, szervezeti megoldásokkal éljen az állam, ha a társadalmi igényekre reflektáló jogi szabályozástól kezdve a közszolgáltatás nyújtása és felhasználása körülményeinek ellenőrzéséig bezárólag valamennyi mozzanatáról maga gondoskodik?

A kérdés megválaszolásához indokolt röviden jellemezni, hogy a kormányzat részéről a kulturális igazgatás szakterületén egyáltalán milyen közszolgáltatások nyújtására kerül(het) sor. Elsőként az állam kulturális igazgatás területén folytatott tevékenységének Magyarország legmagasabb szintủ jogszabályi megalapozására kell kitérni, amely szerint „minden magyar állampolgárnak joga van a művelődéshez”. E deklaráció legitimálja a kormányzat ez irányú tevékenységeit, felhatalmazza a szakterületen felmerülő jogalkotási, szervezési, ellenőrzési feladatainak elvégzésére, amelynek révén az állam (jogi) keretet ad a kulturális igazgatás müköd(tet)ésének, egyúttal a szakmai szabályok érvényesítésének. A felhatalmazás egyben természetesen alkotmányos kötelezettséget is hordoz magában, amely a második generációs jogok közé tartozó kultúrához való jog biztosításának intézményesített keretek között történő megvalósításaként jelenik meg. Milyen értékeket véd az apparátus, melyek a kultúra fogalma alá tartozó szegmensek? Erre a kérdésre az angol antropológus, Tylor kiváló megfogalmazását hívom segítségül: „[A] kultúra vagy civilizáció, tágabban vett anthropológiai értelemben, az a komplex egész, amely magában foglalja a tudást, a hitet, művészetet, az erkölcsöt, a törvényt, a szokást és minden más képességet és sajátosságot, amelyre az ember a társadalom tagjaként szert tesz.” ${ }^{3}$ E megfogalmazásában megjelenik egy kiemelt ismérv: a komplexitás, amely kimutatható a vonatkozó igazgatási szakterületek sokszínűségében is figyelemmel arra, hogy ebbe a körbe tartozik - a teljesség igénye nélkül - a sajtó (média), a tudományok, a közművelődés, illetve a közgyüjtemények igazgatásával foglalkozó szakterület, amely utóbbi kiemelése, definiálása révén eljutottunk a górcső alá vett területhez. A vonatkozó jogszabályi elöŕásokban egzaktan meghatározták a közgyűjtemény fogalmát: „[A]z állam, a helyi önkormányzat, valamint a nemzetiségi önkormányzat, a köztestület és a közalapítvány tulajdonában (fenntartásában) működő, vagy általuk alapított könyvtár, levéltár,

2 Magyarország Alaptörvénye (2011. április 25.) XI. cikk (1) bek.

3 Edward Burnett Tylor (1832-1917) angol antropológus Primitive Culture című művéből (1871). Edward Burnett Tylor: Primitive Culture. Cambridge University Press, 2010. 
muzeális intézmény, kép-, illetve hangarchívumok.”4 A definícióból kiolvasható, hogy az egymástól külön ágazatban működő intézmények együttesen biztosítják a kulturális javak gyüjtését, őrzését, valamint „a tárgyi és szellemi kulturális örökség hozzáférhetővé tételét".

\section{Ki felel a levéltári igazgatás területén felmerülő feladatok ellátásáért?}

A levéltári tevékenység - természetesen az adott kor fejlettségi szintjéhez (az ókorban kezdetben kőtáblákra vésték a szövegeket) mért - létjogosultsága lényegében az írásbeliség megjelenése óta megkérdőjelezhetetlen, a történelmi múlt megismerésének elsődleges forrásául szolgáló, illetőleg a közfeladatok folyamatos ellátásához és az állampolgári jogok érvényesítéséhez nélkülözhetetlen, a nemzet kulturális örökségének részét képező levéltári anyag védelme, folytonos gyarapítása és használata. ${ }^{6}$ Történelmünket végigkísérik a levéltári igazgatás fejlődéstörténetének szervezeti, valamint szakmai változásai; ${ }^{7}$ jelen tanulmányban a rendszerváltozástól kezdődően vizsgálom a területet szervezetelméleti aspektusból. Az 1990-es évek elején a levéltári anyagot keletkeztető gazdasági szereplők helyzete, illetve az állami szervek rendszere is jelentős reformokon esett át, így indokolttá vált a mindenkori törvényalkotó munkássága során folyamatosan alakult, de további, jelentősebb változásra érett vonatkozó joganyag felülvizsgálata, hiszen a jogállami keretek között a közszolgáltatások biztosításával összefüggésben valamennyi ágazatban elengedhetetlen a lehető legmagasabb szintủ szabályozás kidolgozása. E felismerés eredményeként született a köziratokról, a közlevéltárakról és a magánlevéltári anyag védelméről szóló 1995. évi LXVI. törvény (levéltári törvény). A levéltári törvényben megfogalmazott cél ${ }^{8}$ egyértelmü iránymutatást ad a kormányzatnak a szakterületen felmerülő felelőssége tekintetében: az államnak biztosítani kell a közfeladatot ellátó szervek/természetes személyek irathagyatéka maradandó értékủ iratainak ${ }^{9}$ a jövő nemzedéke részére hozzáférhető módon történő megőrzését. Az állam aktív szerepvállalása ezen a területen elengedhetetlen: a levéltári iratanyagról az alkotmányos jogok biztosítására figyelemmel, illetve az adatvédelmi szabályokra tekintettel akként kell gondoskodni, hogy eleget tegyen a benne foglaltak szabályozott keretek között történő megismerhetőségének. E célok megvalósítása érdekében a levéltári törvényünk - összefoglalóan - az alábbi

$4 \quad$ 1997. évi CXL. törvény a muzeális intézményekről, a nyilvános könyvtári ellátásról és a közművelödésről 1. számú melléklet $o$ ) pont.

5 1997. évi CXL. törvény 3/A. \$-ának rendelkezéseiből.

6 1995. évi LXVI. törvény a köziratokról, a közlevéltárakról és a magánlevéltári anyag védelméről, Preambulum.

7 Szükséges megjegyezni, hogy ennek a fejlődéstörténetnek voltak „árnyidőszakai” is, így például az 1950-es évek szocialista ideológiának történő megfelelés kényszere mellett végzett munka nem segítette a szakma fejlődését.

8 Levéltári törvény 1 . $\$$-a.

9 Levéltári törvény $3 . \mathbb{\$} j$ ) pontja. 
közlevéltári alapfeladatok ${ }^{10}$ ellátását írja elő a közlevéltárak ${ }^{11}$ részére: a levéltári iratanyag átvétele, gyüjtése, nyilvántartása, szakszerü kezelése, biztonságos megőrzése, tudományos munkához történő előkészítése, hiteles másolat vagy tartalmi kivonat kiadása, a közfeladatot ellátó szervek, valamint gazdasági társaságok irattári selejtezésének és iratkezelése rendjének ellenőrzése, pusztulásnak indult levéltári anyag konzerválása, levéltár- és történettudományi kutatások elvégzése, a levéltári anyag oktatási, közművelődési célú felhasználásának elősegítése stb.

Fentiekből egyértelműen megállapítható, hogy a területen nyújtott, kulturális szférába tartozó humán közszolgáltatások olyan, nem piaci alapú közszolgáltatások, amelyek igénybevételéből - a vonatkozó jogszabályi rendelkezésesek szabta korlátok mellett - a társadalom egyetlen tagját sem lehet kirekeszteni. A kormányzat az állampolgárok felhatalmazásánál fogva eleget tesz kötelezettségének, és az állami költségvetés biztosítja a szolgáltatás költségét. A levéltári területen nyújtott közszolgáltatások esetében tehát kizárólag az állam, saját tevékenysége útján biztosíthatja hosszú távon is megfelelően az adott feladatok ellátását, csak ez jelenthet garanciát a közérdek megfelelő kiszolgálása tekintetében. A történelem során az apparátusok (helyesen) felismerték, hogy a levéltári iratanyag terjedelme és jelentősége, valamint az ellátni szükséges feladatok heterogenitása ${ }^{12}$ megköveteli egy olyan intézményhálózat kiépítését, amely a szakmaiság legmagasabb szintű képviseletével tud eleget tenni ezen elvárásoknak.

A levéltári törvény szerint Magyarországon napjainkban a levéltárak két típusa működik: a nyilvános magánlevéltárak, valamint a közlevéltárak, amely utóbbiak körébe tartoznak az általános közlevéltárak, az állami szaklevéltárak, valamint a települési önkormányzatok, a köztestületek, a közalapítványok és a jogszabályban meghatározott egyéb közfeladatot ellátó szervek levéltára; a következő bekezdésekben vizsgálódásom az általános közlevéltárak szervezeti kialakításának fejlődéstörténetére irányul.

\section{Az általános levéltárak helyzete a levéltári törvény születéséig}

Saját élményen alapuló gondolattal nyitom a történelmi kitekintést, amelynek során - a részletgazdag történeti, szakmai elemzés igénye nélkül - visszaugrunk az idöben annak érdekében, hogy megértsük, milyen szervezetelméleti és gyakorlati problémák vetődtek fel a napjainkban működő szervrendszer kialakulásáig. A 2007. évben,

10 Lásd bővebben levéltári törvény 13. \$.

11 A közlevéltárak az alapfeladataik végrehajtásának természetesen az illetékességi körükben tesznek eleget.

12 Az iratanyag begyüjtése és megőrzése, emellett gondoskodni kell annak nyilvántartásáról, feldolgozásáról, konzerválásáról, hiteles másolatokat (tartalmi kivonatokat) kell készíteni stb. Álláspontom szerint kiemelt jelentősége van a levéltárak - például az önkormányzati hivataloknál - iratkezelési szempontok alapján folytatott ellenőrzési tevékenységének tekintettel arra, hogy az iratkezelési folyamatok jogszerüségének biztosítása mellett a levéltáros konstruktív hozzáállása sokat segíthet az iratkezelés mozzanatainak rendeltetésszerủ elvégzése szükségességének megértésében. 
a Győr-Moson-Sopron Megyei Önkormányzat fenntartásában működő megyei levéltárak igazgatóival folytatott megbeszélés során megosztottak velem egy - egyéb szakmai fórumokon, illetve szakirodalomban is felvetett - észrevételt a politika és a levéltárügy kapcsolatával összefüggésben: egy jogállamban felértékelődik a levéltárak rendeltetése, mert egy demokratikus rendszer igényli leginkább az olyan szervek (a levéltár) működését, amelyek elősegítik a kormányzati vezetők kijelentéseinek, cselekedeteinek nyomon követhetőségét. Magyarország a II. világháborút követően szocialista uralom alá került, így az ideológiai háttér felépítésével - szovjet mintát követő, nagyfokú központosítással járó - átszervezésre került sor a levéltári rendszerben. ${ }^{13}$ Ennek eredményeként - tekintettel arra, hogy a több megyére kiterjedő illetékességü kerületi levéltárak felállítása főként anyagi okok miatt meghiúsult - 1953-ban felálltak az állami területi levéltárak megyei, illetve fővárosi illetékességgel, ${ }^{14}$ továbbá mellettük az Országos Levéltár működött többek között a bíróságok, illetve a központi államigazgatási szervek irataira kiterjedő illetékességi körrel; a szakmai irányítás pedig a Levéltárak Országos Központja kezében volt. A centralizáció égisze alatt kialakított rendszer egészen az 1967. év végéig állt fenn, majd 1968. január 1. napjával a területi levéltárak a megyei tanácsok ${ }^{15}$ intézményeiként, ${ }^{16}$ azok irányításával folytatták működésüket. ${ }^{17}$ Rövid időn belül megszületett a levéltárügy új, átfogó szabályozása, ${ }^{18}$ amely az államszocialista időszak szülötteként a rendszerváltozást követő első pár évben is meghatározta a levéltári igazgatás jogszabályi hátterét. Az új szabályozás alapján az Országos Levéltár feladatkörét megosztották: az 1945. év előtti időszak iratanyagával kapcsolatos feladatok ellátása során továbbra is az Országos Levéltár, míg az azt követő évek iratanyaga tekintetében az Új Magyar Központi Levéltár járt el. Ezek a szervek, valamint a tanácsi levéltárak általános levéltárként müködtek: az országos levéltárak látták el a központi, az országos jelentőségủ szervek (magánszemélyek) irataival összefüggő teendőket, míg a tanácsi levéltárak megyei (fővárosi) illetékességgel jártak el.

A rendszerváltozás következményeként a jogállamiság helyreállításával új alapokra kellett helyezni az államszervezet felépítését, amely természetesen jelentős kihatással volt az általános levéltárak életére, így ezen időszak lesz történetünk következő állomása. Figyelemmel arra, hogy az 1969-es joganyag már alkalmatlan volt a levéltári igazgatás működtetésére, sürgetővé vált a terület jogi hátterének - az új gazdaság- és társadalompolitikai környezetnek megfelelő - kidolgozása. A „jogalkotási

13 A levéltárakról szóló 1950. évi 29. törvényerejű rendeletben foglaltak alapján került sor az átszervezésre.

14 Kivétel ez alól Győr-Sopron megye, ahol figyelemmel Sopron és környéke nagy terjedelmű, értékes levéltári anyagára két területi állami levéltár jött létre, Győrben és Sopronban. Megtörtént továbbá az azonos székhelyủ városi és megyei levéltárak centralizációja is.

15 Budapesten természetesen a fővárosi tanács intézményeként működött.

16 Győr-Sopron megye mellett Csongrád megyében is két megyei levéltár működött Szegeden és Szentesen (ez utóbbi 1973-ig).

17 A 2045/1967. (VIII. 8.) Korm. határozat alapján.

18 1969. évi 29. törvényerejű rendelet a levéltári anyag védelméről és a levéltárakról szóló, valamint annak végrehajtásáról szóló 30/1969 (IX. 2.) Korm. rendelet. 
gépezet" rohamos sebességgel vetette bele magát az új jogintézmények szabályozásának folyamatába, amelynek eredményeként bár az Országgyűlés életében sürü, nagy horderejủ döntéseket kívánó, tevékeny jogalkotási periódus következett; látható volt, hogy a levéltárügy átfogó rendezésére még néhány évet várni kell. Tekintettel arra, hogy a terület müködőképességének biztosítása érdekében legalább az alapvető kérdésekben meg kellett hozni a szükséges döntéseket, a jogalkotó az önkormányzatokkal kapcsolatos jogi szabályozás útján oldotta meg a helyzetet. Ez logikailag is helyes döntésnek bizonyult, hiszen a területi közigazgatás szervezetének kialakítása során az önkormányzati rendszerek kiépítésére, valamint a levéltárak működtetésére vonatkozó koncepciókban a két terület számos ponton kapcsolódik egymással. Ezen időszakban egy sor, levéltárügyi tekintetben kiemelt jelentőségű jogszabályi rendelkezés látott napvilágot, amely folyamatokról az alábbiakban vázlatosan, időrendi sorrendben teszek említést a terület fokozatos jogi rendezésének bemutatása céljából. Az Országgyủlés 1990. augusztus 3. napján döntött ${ }^{19}$ a levéltári rendszer területi szerveinek jövőbeni helyzetéről a következők szerint: „a megszűnő tanács és szervei jogutóda az önkormányzat". ${ }^{20}$ Az állam tulajdonából az önkormányzatok tulajdonába került a tanácsok kezelésében, illetőleg tulajdonosi irányítása alatt álló oktatási, kulturális, egészségügyi, szociális, sport- és egyéb intézmények vagyona. ${ }^{21}$ Ezzel a korábbi tanácsi levéltárak a megyei (fővárosi) önkormányzatok fenntartásában folytatták működésüket. Az Ötv. az ágazatért felelős (ezen időszakban a művelődési és közoktatási) minisztert bízta meg a helyi önkormányzatok által fenntartott intézmények müködése szakmai követelményeinek, illetve az intézmények (levéltárak) dolgozói képesítési előírásainak rendeleti szinten történő szabályozásával, továbbá a miniszter ellenőrzi ezen elöírások érvényesülését ${ }^{22}$ (ezáltal deklarálásra is került, hogy a szakmai irányításról miként gondoskodik a kormányzat). 1991. május 23-án került elfogadásra azon újabb jogszabály, ${ }^{23}$ amely a következők szerint egyértelműen megjelölte a megyei önkormányzatoknak a levéltárak fenntartására vonatkozó kötelezettségét: a „fóváros, a megye önkormányzata köteles biztosítani a területen működő, illetőleg működött települési önkormányzati szervek és nem központi állami szervek, valamint saját történeti értékủ iratai, továbbá az egyéb helyi jellegủ levéltári anyag átvételét, gyűjtését és őrzését, feldolgozhatóságát és kutathatóságát."24 Ezzel a rendelkezés a vonatkozó hatáskör telepítése mellett, miszerint a közszolgáltatás-szervezéssel összefüggésben felmerülő feladatok ellátására irányuló kötelezettség (felelősség) a (fővárosi) megyei önkormányzatokat terheli, egyúttal meghatározta annak illetékességét is. A szabályozás egyébként konkrét feladatok szabásával is élt a fenntartók irányában, például rögzítette, hogy a helyi önkormányzat közgyülése jóváhagyja az önkormányzati levéltár

19 1990. évi LXV. törvény a helyi önkormányzatokról (Ötv.).

20 Ötv. 103. $\$(3)$ bek.

21 Ötv. 107. $\mathbb{\$}(1)$ bek. $d)$ pontja.

22 Ötv. 79. $\$$ b) pontja.

23 1991. évi XX. törvény a helyi önkormányzatok és szerveik, a köztársasági megbízottak, valamint egyes centrális alárendeltségủ szervek feladat- és hatásköreiről. 
munkatervét, illetve beszámolóját. Kiemelendő továbbá a jogszabállyal kapcsolatban, hogy az ismét lehetőséget biztosított levéltár alapítására és fenntartására a települési önkormányzatok számára. Három megyei jogú város, Székesfehérvár (1992-ben), Győr (1993-ban), valamint Tatabánya (1995-ben) is élt az újjáéledő jogosítvánnyal, amely városok közül Székesfehérvár és Győr már az 1950-es évek elején lefolytatott államosítást megelőzően is működtetett városi levéltárat. A következő, 1991. augusztus 8. napján hatályba lépő, e körben említeni érdemes jogszabály az alábbiak szerint rendelkezett a levéltári anyagok tulajdoni helyzetével kapcsolatban: az önkormányzatok és intézményeik, közüzemeik, valamint jogelődjeik levéltári anyagának tulajdonjogára a levéltári jogszabályok az irányadók; ezen szervek, továbbá a nem központi állami szervek müködésével kapcsolatban keletkezett, rendeltetésszerủen azok irattáraiba tartozó levéltári anyag forgalomképtelen (levéltári anyag megyei, fővárosi levéltárban történő elhelyezése a tulajdonjogot nem érinti). ${ }^{25}$ Szervezetelméleti szempontból fontos még ehelyütt kiemelni, hogy egy további törvényi rendelkezés ${ }^{26}$ szerint 1992. július 1. napjától kezdődően „ahol jogszabály Új Magyar Központi Levéltárat említ, ott Magyar Országos Levéltárat kell érteni", azaz csak a Magyar Országos Levéltár müködik tovább. A rendszerváltozást követően tehát az Országgyűlés - bár adós maradt egy, a levéltári igazgatás területét szabályozó jogszabály megalkotásával, - nem hagyta magára a területet: a levéltárügy átfogó szabályozásának hiányából, valamint a megváltozott társadalom- és gazdaságpolitikai helyzet, illetve a gyökeresen átalakult államszervezet mủködési mechanizmusiból fakadó anomáliák kiküszöbölése érdekében több alkalommal is eleget tett jogalkotási kötelességének.

A levéltári igazgatás szakterületének szabályozása tekintetében a következő mérföldkő az egyes rendelkezései kapcsán korábban már hivatkozott, 1995. június 30. napjával kihirdetésre került levéltári törvény megalkotása volt. Az általános levéltárak száma, szervezeti felépítése a rendszerváltozást követő időszak kapcsán végiggondolt jogi szabályozás során kialakult állapothoz képest változatlanul megmaradt, ebbe a körbe tartoztak a megyei levéltárak, Budapest Főváros Önkormányzatának Levéltára, valamint a Magyar Országos Levéltár (általános levéltárat az Országgyülés hozhat létre, illetve szüntethet meg). A Magyar Országos Levéltár volt a központi általános levéltár, illetékességi körébe tartozott például az Országgyủlés és Hivatala, az autonóm államigazgatási szervek, a minisztériumok, az Állami Számvevőszék iratai stb. A területi általános levéltárak a megyei levéltárak, illetve Budapest Főváros Önkormányzatának Levéltára. Bár a települési önkormányzatok továbbra is élhetnek a levéltár alapításának jogával, ${ }^{27}$ azonban erre - a korábban már említett három

25 1991. évi XXXIII. törvény az egyes állami tulajdonban lévő vagyontárgyak önkormányzatok tulajdonába adásáról.

26 1991. évi LXXXIII. törvény a levéltári anyag védelméről és a levéltárakról szóló 1969. évi 27. törvényerejű rendelet módosításáról.

27 Figyelemmel arra, hogy a vonatkozó jogszabályi előírások a (fővárosi) megyei önkormányzatokhoz telepítették a levéltárak fenntartásának kötelezettségét, a települési önkormányzatok nyilván csak akkor élnek ezzel a lehetőséggel, ha az jelentősebb szakmai előnyöket biztosít (például jobb irattári helyiségben tudja tárolni az iratokat), amely ellensúlyozza az intézmény fenntartásból származó anyagi terhet. 
megyei jogú város mellett - csak egyetlen település, Vác városa esetében került sor 2004-ben..$^{28}$

Napjainkig több alkalommal is módosították a levéltári törvényt, amely egyértelmü jelzése annak, hogy egyes rendelkezései számos egyéb ágazatba tartozó szakterületre is hatással vannak. Változott a normaszöveg egyrészt olyan esetekben, amikor a jogalkotó kifejezetten a szakterületre vonatkozó szabályozás módosítását, kiegészítését tartotta indokoltnak, ${ }^{29}$ másrészt amikor azt valamely - akár más ágazatba tartozó - kap-

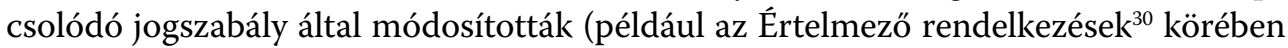
szabályozták a közlevéltárak illetékességére, illetve a levéltári gyűjtőkör meghatározására vonatkozó, ma is hatályos szövegrészt).$^{31} \mathrm{~A}$ teljesség kedvéért ehelyütt indokolt röviden szót ejteni arról, hogy a levéltárügyet természetesen nem kizárólag a levéltári törvény rendelkezései határozzák meg, hanem más jogszabályokkal együtt gondoskodik a terület jogi rendezéséről. A levéltári törvény háttérjogszabályai között találunk még egyéb törvényi szinten megalkotott jogszabályokat, ${ }^{32}$ amelyek rendeltetése egyegy részterület átfogó szabályozása, így egymást kiegészítve szolgálnak alapjául a levéltárügy megfelelő működésének. A mögöttes háttérjoganyag tanulmányozása során találkozunk továbbá olyan rendelkezések sorával, amelyeket a levéltári törvény felhatalmazása alapján fogalmaztak meg: e jogszabályokat egyrészt a Kormány, ${ }^{33}$ másrészt pedig az ágazatért felelős miniszter ${ }^{34}$ által bocsátották ki.

Megállapítható a fentiek tükrében, hogy az apparátus megértette és komolyan vette a levéltárak által nyújtott közszolgáltatások jelentőségét, amelynek eredményeként az állam a jogalkotási tevékenysége révén garanciákkal, működési (működtetési) feltételekkel biztosította a közszolgáltatások színvonalát, illetve ellenőrizte azok betartását. A levéltári törvény jogintézményeinek számbavétele során tehát egy markáns állami jelenlét eszközrendszere (például jogalkotás, szervezetalakítás) jelent meg, a továbbiakban pedig a szervezetalakítás témakörénél maradva egy érdekes elméleti

28 A levéltárnak nem volt jogelődje, tekintettel arra, hogy 1950 előtt Vác város nem tartott fenn levéltárat.

29 2005. évi CXLIX. törvény a köziratokról, a közlevéltárakról és a magánlevéltári anyag védelméről szóló 1995. évi LXVI. törvény módosításáról, 2007. évi XCVII. törvény a köziratokról, a közlevéltárakról és a magánlevéltári anyag védelméről szóló 1995. évi LXVI. törvény módosításáról.

30 A levéltári törvény 3 . $\$$-a.

31 A 2001. évi LXIV. törvény a kulturális örökség védelméről 95. \$-ának (1) bekezdésével iktatták be a megjelölt szövegrészeket. Emellett módosította továbbá például a kulturális javak védelméről és a muzeális intézményekről szóló 1997. évi CXL törvény, a személyes adatok védelméről és a közérdekủ adatok nyilvánosságáról szóló 1992. évi LXIII. törvény stb.

32 Például 1997. évi CXL. törvény, 2009. évi CLV. törvény a minősített adat védelméről, 2001. évi LXIV. törvény stb.

33 Például 335/2005. (XII. 29.) Korm. rendelet a közfeladatot ellátó szervek iratkezelésének általános követelményeiről, 90/2010. (III. 26.) Korm. rendelet a Nemzeti Biztonsági Felügyelet működésének, valamint a minősített adat kezelésének rendjéről stb.

34 Például 7/2002. (II. 27.) NKÖM rendelet a Levéltári Kollégiumról és a levéltári szakfelügyeletről, 14/2010. (XI. 25.) NEFMI rendelet a kulturális javak kiviteli engedélyezéséről, 27/2015. (V. 27.) EMMI rendelet a közlevéltárak és a nyilvános magánlevéltárak tevékenységével összefüggő szakmai követelményekről. 
fejtegetés útvesztőjében keresek válaszokat a közszolgáltatás szervezésével kapcsolatosan gyakorlatban felmerült kérdésekre.

\section{Az általános levéltárak helyzete a levéltári törvény megalkotását követő másfél évtizedben}

Az előző fejezetben felvázolt, a levéltári igazgatás területén kialakított általános levéltári szervezet évekig változatlan formában töltötte be szerepét a közigazgatásban, azonban a háttérben - a levéltár által nyújtott közszolgáltatást igénybe vevő, a levéltári szakterületet nem ismerő állampolgár számára rejtett módon - olyan folyamatok zajlottak, amelyek később indokolttá tették a levéltári törvény korábbi eredményeinek megváltoztatását. A rendszerváltozást követő 15 évben lassú ütemben ugyan, de növekedett a levéltárakban dolgozók személyi állománya, ${ }^{35}$ igaz az egyre növekvő papírhasználattal egyidejűleg a feldolgozásra váró iratanyag mennyisége is nőtt, ráadásul egy sor új kihívással is meg kellett küzdeni, ez pedig az elektronikus felületen történő munkavégzés spektrumának növekedése a technika fejlődése révén. A 2006. évet követően viszont már jelentős létszámcsökkenéssel járó időszak következett, így például a 2005. év és a 2010. év közötti időtartamban nagyságrendileg két közepes méretü intézmény személyi állományának megfelelő létszámmal fogyatkozott meg az ágazat területi szintje. A számok erejét hangsúlyozza, hogy ezen időszakban egy közepes méretű levéltár kapacitásának megfelelő mennyiséggel nőtt a levéltári iratanyag, amellyel összefüggésben nem kizárólag a vele járó megnövekedett munkateher jelentett problémát, hanem az intézmények tárolókapacitásának rohamos mértékủ csökkenése (egyes megyei levéltáraknál lényegében megteltek az irattárak). Ha összevetjük a területi levéltári szervrendszer összköltségvetésének bevételi oldalát a 2005. év és a 2010. év vonatkozásában, a számokból levezethető, hogy átlagosan három közepes méretű intézmény költségvetési bevételének megfelelő mértékủ a különbözet összege.

A levéltári törvény alapján a közlevéltár fenntartója köteles gondoskodni annak rendeltetésszerű működéséhez szükséges költségvetési feltételekről. Miként fordulhat elö, hogy a fenntartó nem tesz eleget ezen - az alkotmányos szinten is megjelenő, a kultúrához való jog biztosításának alapjául szolgáló - közszolgáltatás-szervezési kötelezettségének? A területi levéltárakat érintő, fentiekben részletezett - különösen költségvetési tárgykörbe tartozó - problémák tárgyalása során indokolt egy rövid időre madártávlatból is megvizsgálni a helyzetükre befolyást gyakoroló körülményeket, ugyanis nem lehet reálisan értékelni, ha azokat nem vesszük szemügyre a fenntartó megyei (fővárosi) önkormányzatok oldaláról. 2007. január 1. napjától kezdődően a megyei (fővárosi) illetékhivatalok az Adó- és Pénzügyi Ellenőrzési Hivatal regionális igazgatóságaiba integrálódtak, ${ }^{36}$ természetesen ez a hatáskörelvonás is szűkítette

35 Míg például 1989-ben 522 fő volt a fővárosi és megyei levéltárban dolgozók létszáma, addig 2000-ben 608 fö.

36 Az egyes pénzügyi tárgyú törvények módosításáról szóló 2006. évi LXI. törvény alapján. 
a megyei önkormányzatok „súlyát”, anyagi mozgásterét; illetve a 2008-as gazdasági válság hatásai is érződtek valamennyi ágazatban. Tárgyidőszakban továbbá számos - általában politikai megfontolásból eredő - kormányzati törekvés befolyásolta a közigazgatás területi szerveinek müködési területére vonatkozó szabályokat, amely a regionális szervezési elvet preferálta a Magyarországon történelmi hagyományokon alapuló megyei felosztással szemben. Ezek a reformkísérletek többségében megrekedtek a jogalkotási folyamatok szabályozására vonatkozó feltételek útvesztőiben, jó példa erre, amikor a Kormány - a közigazgatási hivatalok regionális átszervezésével összefüggésben gyakorolt - alkotmányellenes szabályozás ${ }^{37}$ útján létrehozta a regionális közigazgatási hivatalokat. A megyei önkormányzatok szintén nem illettek bele e kormányzati elképzelésekbe, azonban - tekintettel arra, hogy a politikai akarat mögött az Országgyủlésben nem volt meg a minősített többséget igénylö jogszabálymódosításhoz szükséges erő, így - a jogalkotás útján foganatosítható szervezeti változásokra esetükben sem volt lehetőség. Ennek okán egyéb „eszközök” alkalmazására került sor, így például a vizsgált időszakban folyamatosan csökkent a megyei önkormányzatok költségvetésének bevételi összege, azaz évről évre egyre kevesebb forrásból gazdálkodtak. Erre a helyzetre a megyei önkormányzatok vezetői eltérő módon reagáltak. Az egyik megoldásként a hiányzó anyagi forrásokat egyéb úton pótolták, például hitelt vettek fel, vagy kötvénykibocsátásba kezdtek (a kötvénykibocsátásból befolyó bevétel alkalmas volt egyrészt korábbi előnytelen hitelek kiváltására, másrészt a müködési hiány finanszírozására is). Az önkormányzat így tudta biztosítani az intézményeik számára a működésükhöz szükséges anyagi keretet. Más gazdaságpolitikai irányt választó önkormányzatoknál az egyre szűkösebb pénzügyi keret hatására mérsékelni kezdték a kiadásokat, amely hozzáállásnak kezdetben a dologi jellegü kiadások estek áldozatul, illetve a rendelkezésre álló ingatlanállomány használatának racionalizálására (például ingatlanértékesítés/bérbeadás), valamint az azonos szakterületen működő intézmények összevonására is sor kerülhetett. Amennyiben ezen megoldások nem bizonyultak elegendőnek, sor került egyes munkakörökben a dolgozók napi 6, illetve 4 órás munkaidőben történő foglalkoztatására (amely jelentős anyagi terhet rakott az egyébként sem magas bérért dolgozó közalkalmazottak vállára), ${ }^{38}$ rosszabb esetben pedig létszámcsökkentésre. Végső soron egyik irány sem jelentett hosszú távú megoldást, hiszen számos önkormányzat több tízmilliárdos adósságállományt halmozott fel ebben az időszakban, továbbá a megszorítások alkalmazása is jelentősen „megsínylette” mind a funkcionális feladatellátást, mind a szakmai munkát egyaránt (a fenntartó részéről sok esetben már csak a levéltárak működőképességének biztosítása volt a cél, a szakmai érdekek teljes mértékben háttérbe szorultak). A levéltárak az általuk nyújtott közszolgáltatás jellegéből fakadóan is nehezebb helyzetben voltak, hiszen a fenntartók a kisebb „(társadalom)politikai vihar” érdekében inkább

37 Az Alkotmánybíróság a 90/2007. (XI. 14.) AB határozatában megállapította, hogy a közigazgatási hivatalokról szóló 297/2006. (XII. 23.) Korm. rendelet alkotmányellenes, ezért azt 2008. június 30-i hatállyal megsemmisítette. Általában határozott időtartamra szóló, közös megegyezéssel történő kinevezésmódosítások útján. 
alkalmaztak megszorításokat olyan intézmény esetében, ahol nem gyermekek vagy szociálisan rászorultak helyzetét nehezítik (például gyermekvédelmi központ, mentálhigiénés otthon). Mindezeken túlmenően a levéltárak számára az is nehézséget okozott, hogy a piaci érdekérvényesítő képességük jelentős mértékben elmarad a kulturális területen mủködő további intézményekhez (könyvtárak, múzeumok) képest.

\section{A változás iránya, útban a megoldás felé}

A fentiekben foglaltak alapján látható volt, hogy hosszú távon ez a helyzet tarthatatlan. Természetesen a szakmai fórumokon, a fenntartók és az intézmények közötti egyeztetéseken, valamint a kormányzat részéről is megfogalmazódtak a problémákat különböző aspektusból kezelni szándékozó elképzelések, így például a technika fejlődése nyújtotta lehetőségek aktívabb kiaknázása, amely elősegítheti, hogy a levéltár által nyújtott közszolgáltatások „közelebb kerüljenek” az igénybe vevőkhöz, egyúttal - a piaci érdekek komolyabb érvényesítése céljából - a tevékenységük iránti igény és ezzel bevételük is növekedjen. Felvetődött azon lehetőség vizsgálata is, hogy a fenntartó szerv esetleges változása milyen változásokat eredményezne, viszont erre a helyzetre is igaz, hogy az ötletek, javaslatok szintjén megfogalmazott gondolatok konkrét intézkedések foganatosítása nélkül nem nyújthattak érdemi segítséget (természetesen bizakodásra adhattak okot, hogy lesz megoldás, viszont annak egyértelmủ kidolgozása és végrehajtása hiányában feszültséget is generáltak a szakterületen dolgozók körében).

Mielőtt rátérek a helyzet gyakorlati megoldására, röviden szeretném elméleti síkon is összegezni a problémát, amely segítségünkre lehet megérteni, hogy az államnak jelen helyzetben az intézményfenntartás szervezeti kérdéseit vizsgálva milyen megvalósítási lehetőségek között kellett választania. Egy a decentralizációs égisz alatt mủködő szervezeti struktúra esetében az tapasztalható, hogy a közszolgáltatás-szervezésben a helyi szervek befolyása erősödik, hiszen ők rendelkeznek döntési kompetenciával az adott területen. Ezen igazgatási szabályozás mellett gyakori érvként merül fel, hogy így a közszolgáltatásokat igénybe vevők köre „közelebb kerül” a közszolgáltatást nyújtó szervekhez, amely elősegíti a helyi igények hatékonyabb érvényesítését. A másik irány a centralizáció, amely egyértelmüen a központi szervek hatalmát erősíti a helyi szervekkel szemben; a mellette érvelők szerint egy ilyen jelentős, nemzeti érdeket jelentő területnek a képviseletét központilag kell ellátni, továbbá az anyagi források „leosztása” tekintetében is ez a szint a meghatározó. Magyarországon e két lehetőség között kellett választania a jogalkotónak: továbbra is az önkormányzati keretek között gondoskodik a területi levéltárak fenntartásáról, vagy állami kézbe kell venni az irányítást.

A döntés kifejtését megelőzően szükséges kitérni arra, hogy ebben az időszakban a szakma milyen elvárásokat támasztott a jogalkotó felé. Ennek a kérdésnek 
a megválaszolásához a Levéltári Kollégium ${ }^{39}$ által 2010. december 16. napján tartott ülésén létrehozott, a levéltárügy ágazati irányítási, finanszírozási, fejlesztési, valamint a területi általános levéltárak fenntartási kérdéseit vizsgáló levéltári kollégiumi bizottság jelentésében foglaltakat veszem alapul. Alapvető célkitűzésként határozták meg, hogy a közigazgatás folyamatban lévő korszerűsítéséhez illeszkedve szükséges deklarálni a területi általános (megyei, fővárosi) levéltárak jövőbeni működési alapelveit, szervezeti kereteit. A megyei, fővárosi levéltárakat állami fenntartás, azaz - centralizációs irányt követve - központi felügyelet és irányítás alá kell helyezni, illetve ebből következően önálló szakmai irányító hivatal alárendeltségében kell működtetni, különös tekintettel arra, hogy a területi általános levéltárakban őrzött iratok döntő többsége állami szervek által, illetőleg az önkormányzatokhoz telepített államigazgatási eljárások során keletkezett, így fennmaradásuk biztosítása alapvetően állami feladatkörbe tartozik. Prioritásként fogalmazódott meg az összehangolt szakmai irányítás megteremtése, amely a korábbi fenntartói keretek között nem volt megvalósítható (a feltárt, különösen szakmai természetủ nehézségek megoldásától a fenntartók anyagi okokra hivatkozással gyakran nem tettek eleget). Égető problémaként jelentkezett (jelentkezik ma is), hogy az egyes levéltárak technikai, személyi, raktári kapacitásai jelentős mértékben eltérnek egymástól, ami a feladatellátás színvonalbeli különbségei mellett más és más szakmai gyakorlatot eredményez, amely sérti az állampolgárok esélyegyenlőségi jogait. ${ }^{40} \mathrm{~A}$ korábbi fenntartói helyzet következményeként a levéltári munkára vonatkozó ismeretek allokációja, illetőleg a hazai és külföldi tapasztalatok adaptálása meglehetősen esetleges; egyértelműen hiányzott egy összlevéltári oktatási módszertani tudásközpont. A probléma fokozódik (napjainkban is) a kormányzat e-közigazgatási törekvéseivel párhuzamosan: a teljes körű e-közigazgatási rendszerrel szinkronban a levéltárakat fel kellett készíteni az elektronikusan keletkező köziratok fogadására (az e-iratok kezelése, megőrzése a jövőben is megköveteli a levéltárak összehangolt, irányított feladatvégzését). Hatékony, központilag szervezett, fokozott állami szerepvállalást igényelt az intézmények többségét jellemző raktárhiány is. Ebben a helyzetben csak látszólag jelentett megoldást az elektronikus levéltári rendszer megvalósítása, ugyanis a jogszabályok szerint a köziratokat a keletkezésük után 15 évvel adják át a levéltáraknak, így a ma keletkező iratok döntő többsége is egyelöre papíralapon képződik. ${ }^{41} \mathrm{~A}$ jelentés természetesen részletesen kifejtette a fentiekben foglalt elvárásoknak megfelelően kialakítandó szervezeti és szakmai környezet optimális finanszírozásának módját is.

A 2010. évben lebonyolított országos és önkormányzati választásokat követően egyértelmű szándék mutatkozott a kormányzat részéről a területi közigazgatás

39 Lásd bővebben 7/2002. (II. 27.) NKÖM rendelet.

40 Az állampolgárok az önmagukra vonatkozó jogbiztosító iratokhoz az ország különböző pontjain eltérő módon és hatékonysággal férhetnek hozzá, az írott nemzeti örökség megismeréséhez füződő jogaikat eltérö feltételekkel érvényesíthetik.

41 Egy 2010. évi felmérés szerint a rendelkezésre álló raktárkapacitást 30\%-kal haladja meg a még át nem vett iratok mennyisége, és ezen adat mértéke az évek múlásával exponenciálisan nő. 
megreformálására. A vonatkozó szabályozás első mérföldkövének tekinthető, hogy 2011. január 1. napjától kezdődően megalakultak a megyei (fővárosi) kormányhivatalok, amelyeknek a következő években zajlott integrációs folyamata gyökeresen átalakította a területi államigazgatás szervezeti felépítését, továbbá előrevetítették a helyi önkormányzatok igazgatási területére váró változások irányát. ${ }^{42}$

A megyei (fővárosi) önkormányzatok helyzetének rendezésére végül egy 2011. november 25. napjával kihirdetett jogszabály ${ }^{43}$ útján került sor, amelynek vonatkozó rendelkezései szerint 2012. január 1. napjával kezdődően a megyei (fővárosi) önkormányzatok intézményfenntartó szerepköre megszűnt, az intézmények állami fenntartásba kerültek, egyidejűleg sor került az adósságállományuk állami átvállalására 197,6 milliárd forint összegben. A feladat komoly kihívást jelentett, tekintettel arra, hogy számos elkülönült ágazatba tartozó intézmény (kórházak, gyermekvédelmi, oktatási és szociális intézmények, levéltár stb.) helyzetét kellett egyidejűleg rendezni. Kezdetben a kórházak kivételével valamennyi intézmény egy-egy megyei szinten megalakult állami szerv, a megyei intézményfenntartó központ fenntartásába került, ${ }^{44}$ az irányításuk hosszú távú megoldásának az adott ágazatba illeszthető, szakmailag megalapozott szervezeti kereteinek kidolgozásáig. Ezen állami fenntartók alkalmasak voltak arra, hogy felmérjék az egyes intézmények müködési (funkcionális) igényeit, valamint a szakmai elvárások, javaslatok is megfogalmazódtak a szabályozás irányába.

Az általános levéltárakat érintő szervezeti átalakításra is természetesen a levéltári törvény vonatkozó rendelkezéseinek 2012. május 21. napjával elfogadott módosítása ${ }^{45}$ útján került sor. A benyújtott törvénymódosítási javaslat céljaként az általános levéltárak nemzeti szintű levéltári intézményrendszerré alakításának jogszabályi megalapozását deklarálták. Az új szervezeti struktúrában a területi levéltárak beolvadtak a Magyar Országos Levéltár szervezetébe és megyei szintű szervezeti egységekként (tagintézményekként) müködnek, így 2013. október 1. napjával létrejött a Magyar Nemzeti Levéltár. Az általános levéltárak körébe tartozik a Magyar Országos Levéltár (központi általános levéltár), a megyei levéltár és Budapest Főváros Önkormányzata

42 A tanulmányban csak a megyei önkormányzatokat érintő reformok tárgyalására került sor, tekintettel arra, hogy a települési önkormányzatok esetében a városi levéltárak működését egyelőre nem érintették a fenntartó helyzetében bekövetkezett változások. A települések intézményfenntartói szerepkörét tekintve ugyanis a közoktatási és szociális intézmények egy része került állami fenntartásba, illetve a korábban megyei önkormányzati fenntartásban mủködő könyvtárak beolvadtak a városi könyvtárak szervezetébe.

43 2011. évi CLIV. törvény a megyei önkormányzatok konszolidációjáról, a megyei önkormányzati intézmények és a Fővárosi Önkormányzat egyes egészségügyi intézményeinek átvételéről.

44 258/2011. (XII. 7.) Korm. rendelet a megyei intézményfenntartó központokról, valamint a megyei önkormányzatok konszolidációjával, a megyei önkormányzati intézmények és a Fővárosi Önkormányzat egészségügyi intézményeinek átvételével összefüggő egyes kormányrendeletek módosításáról.

45 2012. évi LXI. törvény a köziratokról, a közlevéltárakról és a magánlevéltári anyag védelméről szóló 1995. évi LXVI. törvény és az elmúlt rendszer titkosszolgálati tevékenységének feltárásáról és az Állambiztonsági Szolgálatok Történeti Levéltára létrehozásáról szóló 2003. évi III. törvény módosításáról. 
által fenntartott levéltár. A területi levéltárak intézményi önállósága így megszűnt, azonban a közfeladat-ellátás tartalmi elemei nem változtak: a tagintézmény megyei szinten ellátja a Magyar Nemzeti Levéltár feladatait, a Magyar Nemzeti Levéltár költségvetésén belül az egyes tagintézmények szakmai feladatainak figyelembevételével meghatározott éves elkülönített költségvetési kerettel müködik, vezetőjét (igazgatóját) a Magyar Nemzeti Levéltár főigazgatója nevezi ki a kultúráért felelős miniszter egyetértésével.

\section{Konklúzió}

Tanulmányomban azt a célt tüztem ki magam elé, hogy a közszolgáltatás-szervezés tekintetében az államnak a levéltári igazgatás közelmúltbeli története során betöltött szerepét követem végig a szakterületen zajlott folyamatok alapul vételével. A fentiekben több ízben is sor került a vizsgálódásom egyes állomásai során meggyőződésem kifejtésére, hangsúlyossá téve azt a különböző aspektusból történő megközelítések során, így befejezésként már csak rövid összegzésre kerül sor. Elemzésem eredményeként megállapításaimat ugyanazon gondolat, az állami szerepvállalás lehetséges variánsainak érintése mentén fogalmazom egybe, miként tettem azt a dolgozat előző fejezeteinek kidolgozása során:

A levéltári igazgatás területén a közszolgáltatás-szervezés teendőiről hatékonyan gondoskodó állam aktív szerepe megkérdőjelezhetetlen - különös tekintettel a jogállamban meghatározó jelentőségű alkotmányos felhatalmazásra és egyben kötelezettségre -, egymaga felelős (a társadalom igényeire, valamint a technikai fejlettség adta lehetőségekre figyelemmel) e közszolgáltatások körének deklarálása, nyújtásának biztosítása tekintetében. Magyarországon a megyei (fővárosi) önkormányzati fenntartói szerepét követően a jelenlegi centralista elv alapján kialakított területi levéltári szervezet lehet mủködőképes megoldás (természetesen a városi, és különösen az egyházi levéltárak területen végzett jelentős tevékenysége mellett). Az önkormányzati fenntartói éra (dekoncentráció elve mentén működő megoldás) védelmében azért szükséges megjegyezni, hogy bár a finanszírozási problémák mértéke, az eladósodás vélhetően hibás politikai döntések sorozatának is köszönhető, természetesen nem kizárólag a - költségvetési paramétereket alapjaiban meghatározó - központi kormányzat, hanem a források elosztásáért közvetlenül felelös önkormányzat is szerepet játszik abban, hogy milyen anyagi háttér áll rendelkezésre. Persze az önkormányzati autonómia dacára, amennyiben a központi irányítás nem biztosít elegendő forrást az önkormányzat részére, úgy az csak rövid ideig képes megfelelő szinten tartani egy adott ágazat helyzetét. Álláspontom szerint a jelen centralista felfogás optimálisabb helyzetet teremt a szakterületen: egyrészt mert a központi irányítás nagyobb mértékben képes azonos feltételeket teremteni, illetve egységes irányt mutatni a szakmai munkának; másrészt e levéltári szervezetben nem feltétlenül indokolt, hogy az önkormányzat, illetve a helyi sajátosságok determinálják a szakmai munkát (egy felelős igazgató a szükséges mértékben ennek amúgy is eleget tesz, amennyiben pedig az önkor- 
mányzat ebben magasabb szinten érdekelt, úgy megvan a jogszabályi lehetőség saját levéltár létesítésére). A levéltárak őrző bástyaként szolgálnak nemzeti és történelmi értékeink, identitásunk védelme érdekében, egyetértek a korábban hivatkozott bizottsági javaslatban foglaltakkal abban, hogy fokozott állami szerepvállalás szükséges a levéltárügy gondozása érdekében. Az állami szerepvállalásnak az átpolitizált jellege - miként azt láthattuk a közelmúlt eseményinek bemutatása során - jelentős mértékben érvényesül(het) hatalomgyakorlás során, így a közszolgáltatás-szervezés területén is. Egy demokratikus jogállam vezetőinek politikai/szakmai/erkölcsi felelőssége körében meghozott intézkedések eredménye a megválasztott kormányzat működése révén teljesedhet ki, amelynek alkotmányos kötelessége is egyben, hogy a köz érdekeit szem előtt tartva megfelelően gondoskodjon a közszolgáltatás-szervezés összetett, komplex folyamatairól, így a levéltárügy irányításáról, értékeinek megőrzéséről.

\section{Irodalomjegyzék}

Apró Erzsébet: A magyar levéltári rendszer jövője. Javaslat a levéltári rendszer reformjára. Beszámoló a Magyar Levéltárosok Egyesületének 2007. november 6-án, Budapesten tartott szakmai napjáról. Levéltári Szemle, 57. (2007), 4. 62-67. Online: https://library.hungaricana.hu/hu/ view/LeveltariSzemle_57_2007/?pg=403\&layout=s

Boda Zsolt - Scheiring Gábor: A közszolgáltatások politikai értelmezéséről. Politikatudományi Szemle, 19. (2010), 3. 45-64. Online: www.poltudszemle.hu/szamok/2010_3szam/boda.pdf

Erdész Ádám - Hermann István - Kenyeres István - Mózessy Gergely - Molnár László - Tilcsik György - Tyekvicska Árpád - Á. Varga László: A levéltárügy ágazati irányítási, finanszírozási, fejlesztési, valamint a területi általános levéltárak fenntartási kérdéseit vizsgáló kollégiumi bizottság jelentése. Levéltári Szemle, 61. (2011), 2. 9-53. Online: https://library.hungaricana.hu/ hu/view/LeveltariSzemle_61_2011/?pg=114\&layout=s

Gyimesi Endre: Az állam folyamatos mủködésének letéteményese maga a levéltári anyag... Levéltári Szemle, 61. (2011), 2. 3-8. Online: https://library.hungaricana.hu/hu/view/LeveltariSzemle_61 _2011/?pg=108\&layout=s

Horváth Ferenc: A közszolgáltatások fogyasztása és finanszírozása. A közszolgáltatások marketingje és menedzsmentje. SZTE Gazdaságtudományi Kar Közleményei, JATEPress, Szeged, 2002.

Körmendy Lajos: A levéltárak filozófia- és funkcióváltozásai a 20. és 21. század fordulóján. Levéltári Szemle, 56. (2006), 2. 4-13. Online: https://library.hungaricana.hu/hu/view/LeveltariSzemle_5 6_2006/?pg=121\&layout=s

Sebestyén Tibor: Azállam térvesztése az évszázados térhódítás után. Polgári Szemle, 3. (2007), 9. Online:https://polgariszemle.hu/archivum/36-2007-szeptember-3-evfolyam-9-szam/213-az-allamtervesztese-az-evszazados-terhoditas-utan

Váradi László: A müvelődésigazgatás kézikönyve. Budapest, HVG-ORAC, 2009.

\section{Jogforrások}

Magyarország Alaptörvénye (2011. április 25.)

1991. évi LXXXIII. törvény a levéltári anyag védelméről és a levéltárakról szóló 1969. évi 27. törvényerejű rendelet módosításáról

1995. évi LXVI. törvény a köziratokról, a közlevéltárakról és a magánlevéltári anyag védelméről 
1997. évi CXL. törvény a muzeális intézményekről, a nyilvános könyvtári ellátásról és a közművelödésröl

2001. évi LXIV. törvény a kulturális örökség védelméről

2005. évi CXLIX. törvény a köziratokról, a közlevéltárakról és a magánlevéltári anyag védelméről szóló 1995. évi LXVI. törvény módosításáról

2007. évi XCVII. törvény a köziratokról, a közlevéltárakról és a magánlevéltári anyag védelméről szóló 1995. évi LXVI. törvény módosításáról

2009. évi CLV. törvény a minősített adat védelméről

2011. évi CLIV törvény a megyei önkormányzatok konszolidációjáról, a megyei önkormányzati intézmények és a Fővárosi Önkormányzat egyes egészségügyi intézményeinek átvételéről

2012. évi LXI. törvény a köziratokról, a közlevéltárakról és a magánlevéltári anyag védelméről szóló 1995. évi LXVI. törvény és az elmúlt rendszer titkosszolgálati tevékenységének feltárásáról és az Állambiztonsági Szolgálatok Történeti Levéltára létrehozásáról szóló 2003. évi III. törvény módosításáról

335/2005. (XII. 29.) Korm. rendelet a közfeladatot ellátó szervek iratkezelésének általános követelményeiről

90/2010. (III. 26.) Korm. rendelet a Nemzeti Biztonsági Felügyelet működésének, valamint a minősített adat kezelésének rendjéről

258/2011. (XII. 7.) Korm. rendelet a megyei intézményfenntartó központokról, valamint a megyei önkormányzatok konszolidációjával, a megyei önkormányzati intézmények és a Fővárosi Önkormányzat egészségügyi intézményeinek átvételével összefüggő egyes kormányrendeletek módosításáról

7/2002. (II. 27.) NKÖM rendelet a Levéltári Kollégiumról és a levéltári szakfelügyeletről

14/2010. (XI. 25.) NEFMI rendelet a kulturális javak kiviteli engedélyezéséről

27/2015. (V. 27.) EMMI rendelet a közlevéltárak és a nyilvános magánlevéltárak tevékenységével összefüggő szakmai követelményekről 